\title{
Comparison of Islamic and Conventional Banking Financial Performance during the Covid-19 Period
}

\author{
Ulumuddin Nurul Fakhri \\ Mahad Aly An-Nuaimy, Indonesia \\ Corresponding email: unf_16@yahoo.com
}

\begin{abstract}
Angga Darmawan
BNI Syariah, Indonesia

Article History

Received: October 28 ${ }^{\text {th }}, 2020$ Revised: January 6 ${ }^{\text {th }}, 2021$ Accepted: March 8 $^{\text {th }}, 2021$
\end{abstract}

\begin{abstract}
The COVID-19 pandemic that is spreading in Indonesia has affected economic growth, likewise banks sector. This study aims to determine the financial performance factors that are affected by the COVID-19 pandemic, both in Islamic and conventional banking which are included in the CBGB 2 category so that banks in Indonesia can anticipate it. This study uses the Artificial Neural Network (ANN) method with 6 financial performance variables in the period of January 2020 - September 2020, namely Capital Adequacy Ratio (\%), Operating Expenses / Operating Income (\%), Net Operation Margin (\%), Landing on Deposits. Ratio (\%), Short Term Mismatch (\%) which are used as the independent variable, as well as Return on Assets which is used as the dependent variable. The results showed that the COVID-19 pandemic affected financial performance factors in the form of a Funding to Deposit Ratio of 35.21\%; Short Term Mismatch of $26.92 \%$ and Net Operation Margin of 26.92\% in Islamic banking. Whereas in conventional banking, Operating Expenses to Operating Income was $72.87 \%$ and the Capital Adequacy Ratio was $17.31 \%$. This result is also in line with previous research where Islamic banking is more vulnerable than conventional banking in facing financial crises.
\end{abstract}

Keywords: Covid-19, Artificial Neural Network, banking financial performance. JEL Classification: G01, G21, L25

Type of paper: Research Paper

@ IIIEF 2021 published by Universitas Muhammadiyah Yogyakarta, Indonesia All rights reserved

DOI:

Web:

https://doi.org/10.18196/ijief.v4i0.10080 https://journal.umy.ac.id/index.php/ijief/article/view/10080

Citation:

Fakhri, U. N., \& Darmawan, A. (2021) comparison of Islamic and conventional banking financial performance during the covid-19 period. International Journal of Islamic Economics and Finance (IJIEF), 1(2),19-40. DOI: https://doi.org/10.18196/ijief.v4i0.10080. 
Fakhri \& Darmawan | Comparison of Islamic and Conventional Banking Financial Performance during the Covid-19 Period

\section{Introduction}

\subsection{Background}

Corona Virus Disease (COVID-19) is a new virus whose spread has created uproar all around the world. The closure of business centers has become a sign of a financial crisis in many countries. Economic growth in several countries in the world experienced a significant decline, including China in Q1 2020 experiencing an economic decline of $-6.8 \%$ (yoy), although in Q2 2020 it experienced an increase to 3.2\% (yoy). The United States, Singapore, South Korea, Hong Kong and the European Union saw significant decreases. For America, economic growth in Q2 in 2020 reached -9.5\% (yoy), Singapore in Q2 in 2020 was $-12.6 \%$ (yoy), South Korea reached $-2.9 \%$ (yoy), Hong Kong reached $-9.0 \%$ (yoy), and the European Union reached $-14.3 \%$ (yoy). The figure can be seen in Figure 1.

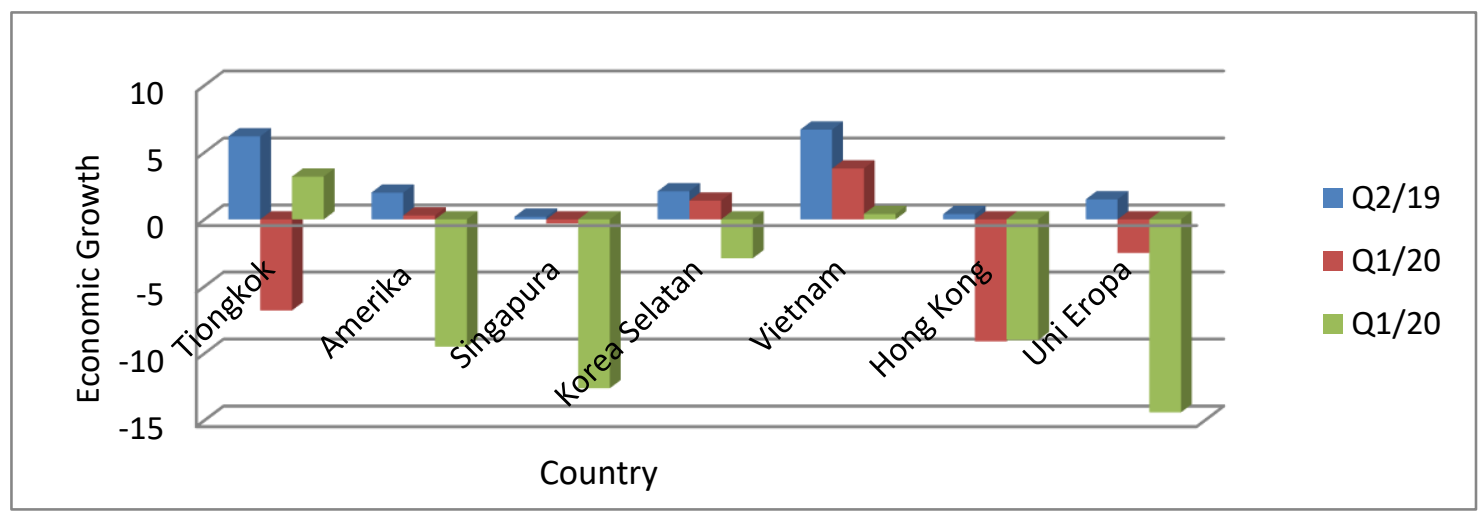

Figure 1. Economic Growth Development in the World Source: Badan Pusat Statistik [BPS], 2020

Indonesia is no exception, the impact of the spread of COVID-19 has caused Indonesia's economy to experience a slowdown. According to Bank Indonesia, economic growth in the first quarter of 2020 experienced a slowdown, namely $2.97 \%$ (yoy) compared to economic growth in 2019 of $4.97 \%$ (yoy). Meanwhile, in the second quarter of 2020, it became $-5.32 \%$ from 2019. The slowdown in Indonesia's economic growth due to COVID-19 has caused domestic demand to decline (Bank Indonesia, 2020).

The economic slowdown in Indonesia also had an impact on the financial performance of banks in Indonesia. The impact of this slowdown can be seen in the table below. 
Fakhri \& Darmawan | Comparison of Islamic and Conventional Banking Financial Performance during the Covid-19 Period

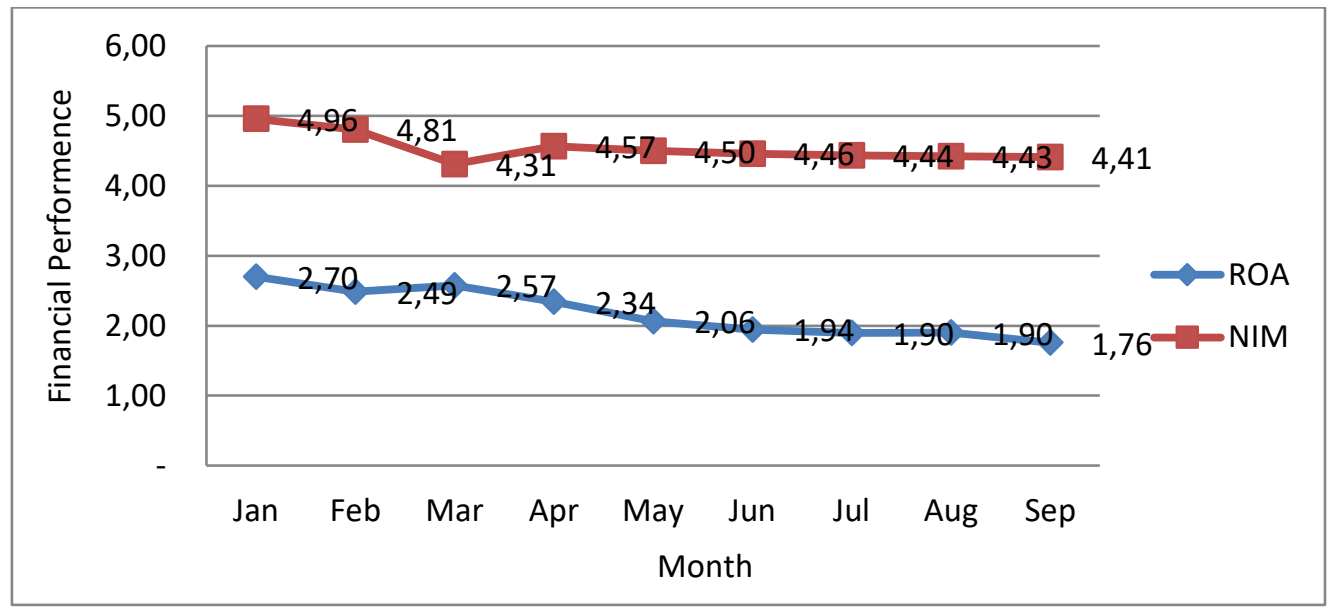

Figure 2. Financial Performance of Conventional Commercial Banks in 2020 Source: Otoritas Jasa Keuangan [OJK], 2020

The data in Figure 2 shows a decline in the performance of Indonesian banking during the COVID-19 period. Where, the NIM (Net Interest Margin) in the picture above always decreases from January to September 2020 even though the decline is not significant. The decline in NIM (Net Interest Margin) was $4.98 \%$ in January to $4.41 \%$ in September 2020. Likewise, ROA (Return on Asset) experienced a significant decrease from $2.70 \%$ in January to $1,76 \%$ in September 2020 (Statisik Perbankan Indonesia [SPI], 2020).

From the data above, it can be concluded that Bank in Indonesia experienced a decline in financial performance during the COVID-19 pandemic spreading in Indonesia (Nugroho, Utami, \& Doktoralina, 2020). Therefore, this study wants to find out and compare what factors affect the decline in financial performance in Islamic banking and conventional banking which is specifically for the category CBGB 2 (Commercial Bank - Group of Business) during the COVID-19 pandemic. In previous research (Fakhri et al., 2019) (Ali, 2020) stated that the factor of decline in financial performance in Islamic banking was influenced by external factors.

This research focuses on the internal factors of Islamic and conventional banking during the COVID-19 pandemic. These internal factors are CAR (Capital Adequacy Ratio), FDR (Financing to Deposit Ratio), NPF (Net Performing Financing, Savings, BOPO (Operational Costs and Operational Costs), and NOM (Net Operational Margin) by using Profitability as a reference. Murthy and Sree, 2003; Alexandru et al., 2008 in their research said that in measuring profitability, several ratios can be used such as Return on Assets (ROA), Return on Equity (ROE), and Net Interest Margin, while Khawish ( 2011) states that ROA can observe a bank's ability to generate profits by utilizing assets (equity and debt) owned by the company. Thus, ROA shows how much efficiency of banking resources can be used to generate profits. 
Fakhri \& Darmawan | Comparison of Islamic and Conventional Banking Financial Performance during the Covid-19 Period

This is a reference for ROA in seeing the influence of other performance factors.

In a previous study, Fakhri et al. (2020) stated that the bankruptcy rate of Islamic banking in CBGB 2 is in the gray zone and is ranked 3. This means that it is very vulnerable to external conditions, such as inflation. Meanwhile, conventional banking is in a safe zone and is ranked 1 which indicates that the financial performance of conventional banks in CBGB2 is classified as safe. This research was conducted in a stable state economy. The purpose of this study was to determine the effects of financial performance during the Covid-19 period. By knowing the results of this study, it is hoped that banks in Indonesia can quickly make decisions so that the financial condition of banks in Indonesia becomes stable.

In addition, by knowing the financial performance of Indonesian Banking based on result of this research, the public can help to save Indonesian banking, especially Islamic banking, from the financial crisis due to the COVID 19 pandemic. One of the ways is saving their idle funds in Indonesian banks, especially Islamic banks.

\section{Literature Review}

\subsection{Background Theory}

\subsubsection{Banking Financial Performance}

Banking financial performance is regulated in the Financial Services Authority (POJK) No. 32 / POJK.03 / 2016 concerning Transparency and Publication of Bank Reports. In this regulation, there is a variable financial performance. The variables of Indonesian banking financial performance can be explained as follows:

a. Return On Asset (ROA)

Return on Asset (ROA) can determine the relationship between organizational structure and financial performance of retail banks, so that it can formulate organizational strategies in dealing with financial distress. ROA focuses on the company's ability to generate profits in company activities (Mawardi, W. 2004: 85). In a Circular Letter of the Financial Services Authority (SEOJK) explains that Return on Assets (ROA) is a comparison between profit before tax and the average total assets in one period (Surat Edaran Otoritas Jasa Keuangan [SEOJK], 2019). 
Fakhri \& Darmawan | Comparison of Islamic and Conventional Banking Financial Performance during the Covid-19 Period

In this study, return on assets (ROA) is one of the variables that can affect the bankruptcy of Islamic banks because the return on assets can be used to measure how much a Islamic banking makes a profit by utilizing its assets. With the greater the return on assets, the performance of Islamic banking is getting better. When the return on assets has increased, it will increase the profits that will be enjoyed by investors (Husnan, 1998). The ROA formula according to the Financial Services Authority Circular Letter (SEOJK) is:

$\begin{aligned} & \text { Return On Assets } \\ & (\text { ROA })\end{aligned} \quad=\frac{\text { Earning Before Tax }}{\text { Total Assets }} \times 100 \%$

b. Capital Adequacy Ratio (CAR).

Capital Adequacy Ratio is a ratio that shows how much capital capacity in banks can absorb the risk of credit failure that will occur so that the higher the level of the capital ratio, the bank is healthier, and vice versa (Muljono, 1999). The formula for obtaining the capital adequacy ratio has been described by OJK in an OJK circular letter, namely:

$$
\begin{aligned}
& \text { Capital Adequacy Ratio } \\
& \text { (CAR) }
\end{aligned} \quad=\frac{\text { Equity }}{\text { Risk Weighted Assets }} \times 100 \%
$$

c. Operational Costs and Operating Income

Puspitasari's research (2015: 261) states that there are 3 (three) measures towards efficiency including 1 . The same input produces a larger output, 2. Smaller inputs produce the same output, and 3. Large inputs will produce output the greater one. To achieve the Bank's efficiency level, it can be measured through the ratio of Operational Costs to Operating Income (BOPO) (POJK no. 06 / POJK.03 / 2016). The BOPO ratio in the research of Setiawan (2008), Surahman (2007), Susanto and Njit (2012) includes this ratio in influencing banking performance. The formula for the BOPO ratio is:

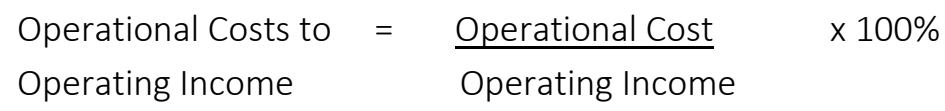

\section{d. Net Operational Margin (NOM)}

Net Operation Margin (NOM) in a Islamic Bank means the same as Net Interest Margin (NIM) in Conventional Banks because in the regulation of the Financial Services Authority (POJK) no. 6 / POJK.03 / 2016 explains that to achieve the level of efficiency of the Bank is measured by the ratio of $\mathrm{Net}$ Interest Margin (NIM) or Net Operating Margin (NOM). Aviliani's research, et al. (2015) includes NIM or NOM as a factor that is considered to affect profitability. The NOM ratio is used by banks to measure the ability of management to manage their capital to obtain profits from the provision of funds to the public to generate net profits. Net profit is obtained from the entire distribution of funds after deducting profit sharing and deducting 
Fakhri \& Darmawan | Comparison of Islamic and Conventional Banking Financial Performance during the Covid-19 Period

operating expenses. The NOM formula following the provisions of the financial services authority (SEOJK) circular letter is:

$$
\text { Net Operational }=\frac{\text { (Income after Revenue Sharing-Oper }}{\frac{\text { Cost) }}{\text { Margin (NOM) }}} \times 100 \%
$$$$
\text { e. Financing to Deposit Ratio (FDR) }
$$

Financing to Deposit Ratio (FDR) in Islamic banks is the same as the LDR Loan to Deposit Ratio in conventional banks in its meaning, where in Bank Indonesia regulation no. 17/11 / PBI / 2015 that the ratio of loans to third parties in Rupiah and foreign currencies, excluding loans to other banks. The formula for the Loan to Deposit Ratio according to Bank Indonesia regulations is:

\begin{tabular}{|c|c|c|}
\hline Financing to & & Total Financing \\
\hline $\begin{array}{c}\text { Deposit Ratio } \\
\text { (FDR) }\end{array}$ & $=$ & $\begin{array}{c}\text { Total Third Party } \\
\text { Funds }\end{array}$ \\
\hline
\end{tabular}

\section{f. Short Term Mismatch Ratio (STMR)}

This ratio calculates the number of short-term assets compared to shortterm liabilities so that the ability of Islamic banks to meet their short-term liquidity needs is known. Financial Services Authority Circular Letter (SEOJK) Short Term Mismatch Ratio is included in the assessment of bank financial performance. In the research of Cahyani and Saepudin (2015), it is explained that the Short Term Mismatch Ratio is an indicator of the quality of banking performance in Indonesia. The Short Term Mismatch Ratio formula is:

$\begin{gathered}\text { Short Term } \\ \text { Mismatch Ratio } \\ \text { (STMR) }\end{gathered}=\begin{gathered}\text { Short Term-Assets } \\ \text { Short Term- } \\ \text { Liabilities }\end{gathered}$
$100 \%$

\subsubsection{Artificial Neural Network Model (ANN)}

The Artificial Neural Network (ANN) model is a problem-solving model by imitating the intelligence of the human brain, especially in analyzing classification and pattern recognition. Biological neurons in humans are imitated by the Artificial Neural Network Model (ANN) using a computational model. Al-Osaimy's research (1998: 34) says that in decision making, new classification and prediction. Artificial Neural Networks construct "neouron" systems to model previously solved results, just as humans apply knowledge gained from past experiences to new problems or situations. In addition, the Artificial Neural Network (ANN) consists of neurons that form interconnected groups. By using algorithmic functions, each neuron processes information (receives input and provides output) from data (Anwar and Watanabe, 2011). 
Fakhri \& Darmawan | Comparison of Islamic and Conventional Banking Financial Performance during the Covid-19 Period

\subsection{Previous Studies}

There are so many previous studies that discuss the financial performance of Islamic and conventional banking, including research by Ika and Abdullah (2011) which deals with a comparative study of the financial performance of Islamic and conventional banking in Indonesia. This research shows that Islamic banks are more liquid than conventional banking.

In another study, Tho'in (2019) examine the comparison of financial performance between Islamic and conventional banking in Indonesia before and after the formation of the ASEAN Economic Community (AEC). This study shows that out of the five variables being compared, only ROA and ROE showed a difference between before and after MEA, while for the other three variables before and after the implementation of MEA was fixed.

Meanwhile, there is another similar research by Fakhri et al. (2019) which deals with the comparison of the financial performance of Islamic and conventional banking in Indonesia to achieve sustainable growth. This study also uses an Artificial Neural Network (ANN) and results that Islamic banking is significantly affected by external factors (inflation), namely $70.3 \%$, while conventional banks are also influenced by external factors (inflation) but only $24.3 \%$. This research shows that Islamic banking is more vulnerable to external factors, namely inflation.

This research wants to continue the research of Fakhri et al. (2019) during the COVID-19 pandemic, where external factors (inflation) are very influential at this situation. So this research wants to find out the internal factors that are very influential with the conditions during the COVID-19 pandemic using Artificial Neural Network (ANN) model.

\section{Methodology}

\subsection{Data}

Riono (2020), who is an Epidemiology and Biostatistics expert from Faculty of Public health of The University of Indonesia said that Covid-19 has been circulating in Indonesia since January 2020. Even though, the government announced that Covid-19 entered Indonesia in March 2020. So this research takes data from January 2020 to September 2020.

The data set consists of 6 financial performance variables for the period January 2020 - September 2020, namely Capital Adequacy Ratio (\%), Operating Expenses / Operating Income (\%), Net Operation Margin (\%), Landing to Deposit Ratio (\%), Short Term Mismatch (\%) in Islamic banking

International Journal of Islamic Economics and Finance (IJIEF), 3(SI), 19-40 | 25 
Fakhri \& Darmawan | Comparison of Islamic and Conventional Banking Financial Performance during the Covid-19 Period

and conventional CBGB 2 (Commercial Bank - Group of Business) which are used as independent variables. CBGB 2 (Commercial Bank - Group of Business) is a category of commercial banks, both conventional and Islamic, which have core capital between IDR 1 trillion - IDR 5 trillion. This classification is based on Financial Services Authority Regulation (POJK) No. 6 / POJK.03 / 2016 about Business Activities and Office Networks Based on Bank Core Capital. Judging from the core capital, the business activities of each CBGB category are different.

Meanwhile, the growth variable Return on Assets (ROA) in that period was used as the dependent variable. All data used is obtained from the website of the Financial Services Authority (OJK). This study uses an Artificial Neural Network (ANN) model with a quantitative approach.

Furthermore, the data will be processed using an Artificial Neural Network to obtain the factors that affect the financial performance of Islamic and conventional banking. Finally, the results of the factors that influence the financial performance of Islamic banking will be compared with the factors that affect conventional financial performance by confirming the results of previous studies, namely the research of Fakhri et al. (2020).

\subsection{Model Development}

There are three reasons for processing all data in order to change the incoming data to the new version. (1) The level of importance in determining the output is reflected in the data size, (2) Before training the network, by facilitating the initialization of random weights, (3) to avoid different measurements due to different input units, data normalization is carried out. Furthermore, Alyuda provides a complete search feature for designing neural network architectures.

This research needs to combine several neurons into a multilayer structure called a neural network to have the power to solve problems of pattern classification and recognition. Therefore, this study uses a feed-forward multi-layer network, which is the type of neural network most commonly used today. The feed-forward multi-layer network consists of an input layer, a hidden layer. and an output layer.

Specifically, the input layer is the layer directly connected to outside information. All data in the input layer will be passed to the hidden layer as the next layer. Meanwhile, the hidden layer functions as a detection feature for the input signal and releases it to the output layer. Finally, the output layer is considered to be the aggregator of detected features and the generator of responses. In the network, the output from the output layer is 
Fakhri \& Darmawan | Comparison of Islamic and Conventional Banking Financial Performance during the Covid-19 Period

a function of the linear combination of hidden unit activations; the hidden unit activation function is a non-linear function of the weighted input sum. Mathematically, the model can be written as follows (Anwar and Watanabe, 2011):

$$
Y=f(x, \theta)+\varepsilon
$$

Where :

$\chi=$ the vector of explanatory variables

$$
\begin{aligned}
& \theta \theta=\text { weights vector (parameters) } \\
& \varepsilon=\text { the random error component }
\end{aligned}
$$

Then, Equation (8) is an unknown function for estimating and predicting from the available data. Thus, the model can be formulated as:

$$
y=f\left[V_{0}+\sum_{j=1}^{m} h\left(\lambda j+\sum_{i=1}^{n} x_{i} w_{i j}\right) v_{j}\right]
$$

Where:

$$
\begin{array}{ll}
\mathrm{Y} & =\text { network output } \\
\mathrm{F} & =\text { output layer activation function } \\
\mathrm{V}_{0} & =\text { output bias } \\
\mathrm{m} & =\text { number of hidden units } \\
\mathrm{h} & =\text { hidden layer activation function } \\
\lambda_{j} & =\text { hidden unit biases }(j=1, \ldots, \mathrm{m}) \\
\mathrm{n} & =\text { number of input units } \\
\mathrm{x}_{\mathrm{i}} & =\text { inputs vector }(\mathrm{i}=1, \ldots, \mathrm{n}) \\
\mathrm{w}_{\mathrm{ij}} & =\text { weight from input unit } \mathrm{i} \text { to hidden unit } \mathrm{j} \\
\mathrm{v}_{\mathrm{j}} & =\text { weights from hidden unit } \mathrm{j} \text { to output }(\mathrm{j}=1, \ldots, \mathrm{m})
\end{array}
$$

The model of the Artificial Neural Network (ANN) is described in Figure 3.

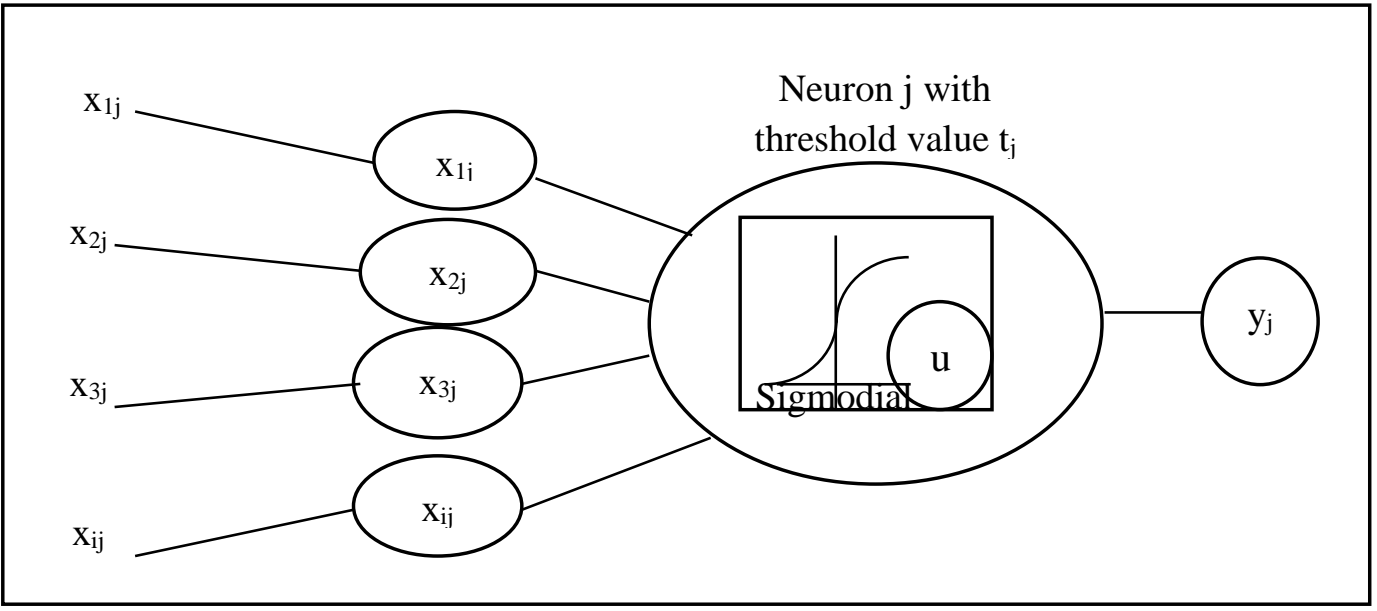

Figure 3. Artificial Neural Network Model

(Source: Anwar and Watanabe, 2011) 
Fakhri \& Darmawan | Comparison of Islamic and Conventional Banking Financial Performance during the Covid-19 Period

From Figure 3, the configuration used for the learning process is as follows:

(1) The logistic function is selected for all neurons.

(2) The sum of the squared errors is chosen to minimize the output error. This is the sum of the squared difference between the model's actual and output values.

(3) The network output is set between 1 and -1 because the logistic activation function is used where 1 is for growth in financial performance levels and -1 for decreasing levels of financial performance.

Then, to train ANN requires special conditions to avoid over fitting, such as; using Batch Back Propagation in order to learn, the speed and momentum of learning is set at 0.1 and for completeness, the process must end when the mean squared error decreases by less than 0.000001 or the model completes 20,000 iterations, whichever occurs first. The results of the data exercise formed a mean of 20.6 and a standard deviation of 2.17 for conventional banking and the results for Islamic banking are a mean of 25.39 and a standard deviation of 0.8. In addition, from training using Batch Back Propagation, the CRR (Correct Classification Rate) value in conventional banking was $71.4 \%$ while in Islamic banking the CCR value was $57.1 \%$. Finally, this study uses the same logarithm between conventional banks and Islamic banks, namely the $\mathrm{N}$ logarithm (5-1-1) in the learning and testing process that will be carried out later. This happens because of limitations in data processing using ANN.

\subsection{Method}

Artificial Neural Network (ANN) is a method that resembles the way humans think. This research uses ANN (Artificial Neural Network) to determine the factors that affect the decline in financial performance. Research in the field of economics, especially in the fields of business and financial management, banking and corporate failures, stock price prediction, and bond rating has developed research especially for prediction using the Artificial Neural Network (ANN) method. Research on the performance of banks, especially Islamic banks using a neural network was studied by Al-Osaimy (1998), AlShayea and El-Refae (2012), the failure of conventional banks using the neural network was studied by Tam (1991), Tam and King (1992) and Boyacioglu et al (2009). Meanwhile, Oodom and Sharda (1990), Altman et al. (1994), Almilia and Kritijadi (2003), Hamdi (2012), and Bredart (2014) examined company bankruptcy using a neural network. In addition Setiawan (2008) uses artificial neural networks in researching stock price predictions.

In all of these studies, the artificial neural network model outperformed traditional statistical methods such as discriminant analysis and logistic regression. In addition, the most commonly used approach above and in other 
Fakhri \& Darmawan | Comparison of Islamic and Conventional Banking Financial Performance during the Covid-19 Period

studies is the backpropagation neural network model (Al-Osaimy, 1998) (Anwar and Watanbe, 2011). Anwar and Hasan (2016) in their research used the ANN method to predict a decline in the financial performance of Islamic banks where the prediction results obtained $85 \%$. These results indicate that the ANN method is very relevant to use in this study. Likewise, with the research of Fakhri et al (2020) where the results of this study prove that the Artificial Neural Network (ANN) is very relevant in determining factors that affect the financial performance of Islamic and conventional banking.

\section{Results and Analysis}

\subsection{Results}

The results of data analysis will be presented in 2 stages. The first stage will present the results of the factors that affect the decline in the financial performance of Islamic banking. Second, the results of the factors that influence the decline in the performance of conventional banking will be presented.

\subsubsection{Islamic Banking CBGB 2}

Figure 4 shows that the factors affecting the financial performance of Islamic banking during the COVID-19 pandemic are:

1. Funding to Deposit Ratio of $35.21 \%$

2. Net Operation Margin of $27.83 \%$

3. Short Term Mismatch of $26.92 \%$

4. Operating Expenses / Operating Income of 7.32\%

5. Capital Adequacy Ratio of $2.72 \%$

\begin{tabular}{|c|c|c|c|}
\hline \multicolumn{4}{|l|}{ Network Statistics } \\
\hline 岾 Ш & 「 Real-time $\approx$ & 田 & \\
\hline Input column name & \multicolumn{3}{|c|}{ Importance, $\%$} \\
\hline CAR & \multicolumn{3}{|l|}{2,718995} \\
\hline NOM & \multicolumn{3}{|l|}{27,832991} \\
\hline OEOR & \multicolumn{3}{|l|}{7,31562} \\
\hline STM & \multicolumn{3}{|l|}{26,922931} \\
\hline FDR & \multicolumn{3}{|l|}{35,209463} \\
\hline Preprocessing & Design Training & Testing & Query \\
\hline
\end{tabular}

Figure 4. Factors that affect the decline in the financial performance of Islamic Banking CBCG 2 
Fakhri \& Darmawan | Comparison of Islamic and Conventional Banking Financial Performance during the Covid-19 Period

The first and third biggest influence from the above results on liquidity performance with a total of $62.13 \%$, namely Funding to Deposit Ratio (FDR) of $35.21 \%$ and Short Term Mismatch of 26.92\%. Meanwhile, the factor that has an effect on the second order is the performance of Profitability or Net operation Margin (NOM) of 26.92\%. Thus Covid-19 greatly affects the liquidity factor where this factor is very important in the ability of a company to pay its short-term obligations and debts. Although the profitability factor is not too significant, however this factor can affect the ability of a company to generate profits within a certain period.

These results prove that Islamic banking is still vulnerable in facing external factors. These results are also in accordance with research (Fakhri, 2020) where Islamic banking is in third place. According to the Financial Services Authority Regulation No. 8 / POJK.03 / 2014 which refers to Bank Indonesia regulation no. 9/1 / PBI / 2007 regarding the assessment of the soundness level of Islamic Commercial Banks and Islamic Business Units, rating 3 indicates that asset quality is quite good but is expected to decline if improvements are not made. Policies and procedures for providing financing and risk management from financing have been implemented fairly well and in accordance with the scale of the bank's business, however, there are still insignificant weaknesses and / or are well documented and administered.

\subsubsection{Conventional Banking CBGB 2}

From Figure 5, we can see the factors that affect financial performance due to the impact of the COVID-19 pandemic, as follows:

1. Operating Expenses to Operations Revenue of $72.87 \%$.

2. Capital Adequacy Ratio of $17.31 \%$

3. Liquid Asset Ratio of $5.35 \%$

4. Landing to Deposit Ratio 3.51\%

5. Net Interest Margin of $0.95 \%$

\begin{tabular}{|c|c|c|}
\hline \multicolumn{3}{|l|}{ Network Statistics } \\
\hline 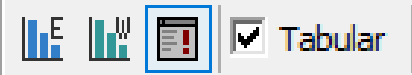 & 「 Real-time $\approx$ & 田 \\
\hline \multicolumn{3}{|l|}{ Input column name } \\
\hline$\overline{\text { CAR }}$ & \multicolumn{2}{|l|}{17,314397} \\
\hline NIM & \multicolumn{2}{|l|}{0,9463} \\
\hline OE/OR & \multicolumn{2}{|l|}{72,873489} \\
\hline LAR & \multicolumn{2}{|l|}{5,35384} \\
\hline LDR & \multicolumn{2}{|l|}{3,511974} \\
\hline
\end{tabular}

Figure 5. Factors affecting the financial performance of conventional banking CBGB 2 
Fakhri \& Darmawan | Comparison of Islamic and Conventional Banking Financial Performance during the Covid-19 Period

The results above prove that $C B G B 2$ conventional banking is more stable in facing crises due to the COVID-19 pandemic. This is because the most dominant influence is Operating Expenses to Operations Revenue of $72.87 \%$, although Operating Expenditures on Operating Income are included in the Profitability factor, the handling of this factor is quite simple, which is by efficiency. The profitability factor does not have a significant effect, and the Capital Adequacy Ratio (CAR) also has no significant effect, which is only $17.31 \%$

These results prove that Conventional Banking is still highly ready to face external factors. This result is also in accordance with research (Fakhri, 2020) where conventional banking is in the first rank. According to the Financial Services Authority Regulation No. 8 / POJK.03 / 2014 which refers to Bank Indonesia regulation no. 9/1 / PBI / 2007 regarding Soundness Level Products for Islamic Commercial Banks and Islamic Business Units, rating 1 reflects that the financial condition of the Bank or UUS is classified as very good in supporting business development and anticipating changes in economic conditions and the financial industry. The Bank has a strong financial capacity to support development plans and the risks of significant changes in the banking industry.

\subsection{Robustness Test}

\subsubsection{Islamic Bank CBGB 2}

The results of the financial performance factors (Figure 6) are formed from the logarithm of $\mathrm{N}^{(5-1-1)}$, where the logarithm produces an ROC (Receiver Operating Characteristics) curve of $66,7 \%$. ROC curves display network performances across various possible accept/reject limits. The larger the area under the curve, the better the network is formed. Like any other test chart, the ROC curve can be plotted separately for training, testing and validation sets or for all of them. Below are the logarithm of $N^{(5-1-1)}$ and the resulting KOP curve for the logarithm of $N^{(5-1-1)}$. 
Fakhri \& Darmawan | Comparison of Islamic and Conventional Banking Financial Performance during the Covid-19 Period

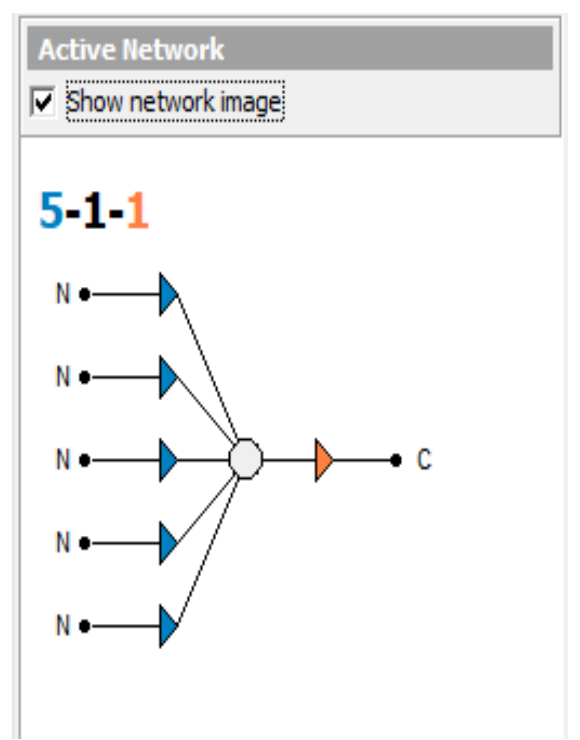

Figure 6. Logarithm of Islamic Banking CBGB 2

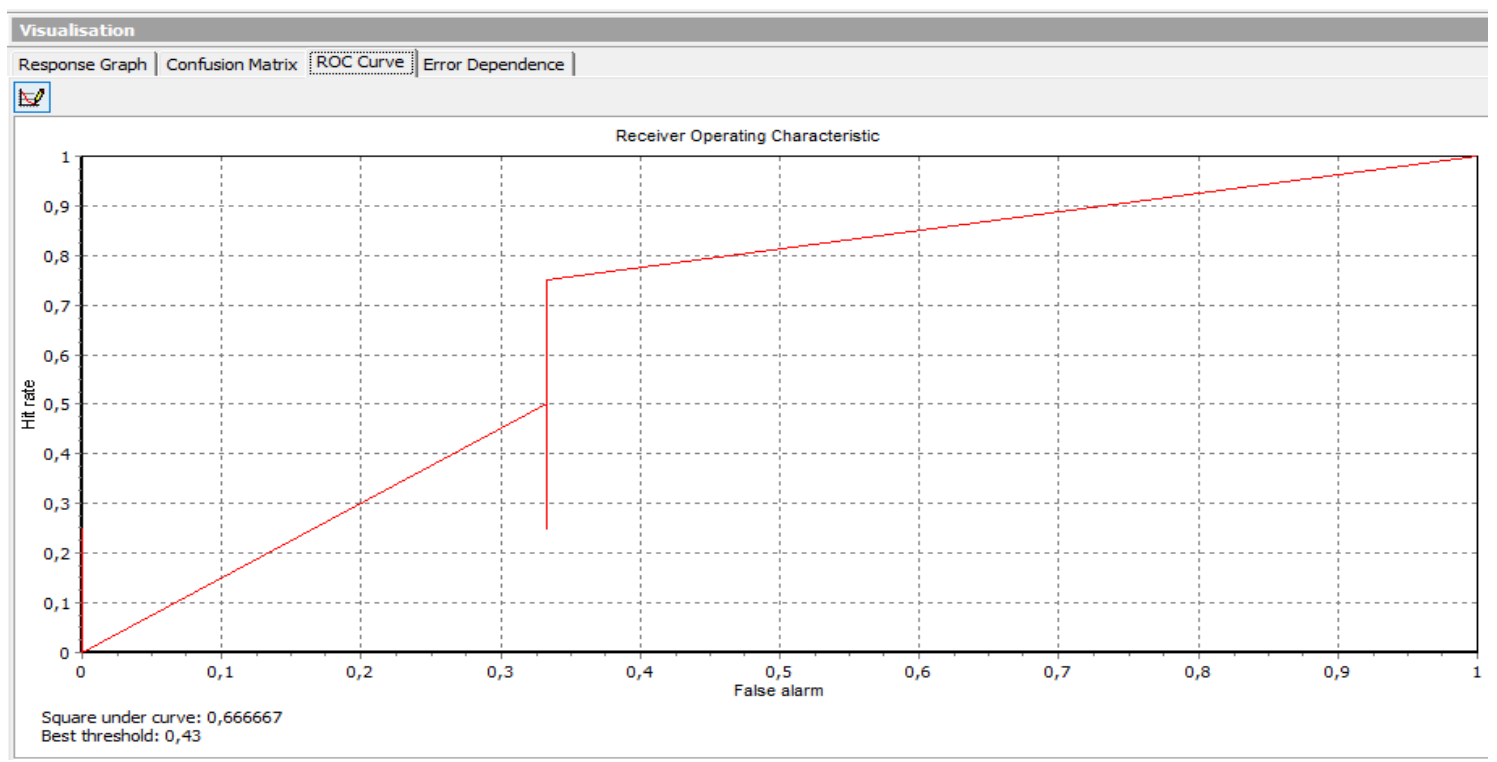

Figure 7. Results of the ROC Curve for Islamic Banking CBGB 2

The results of the ROC curve (Figure 7) confirm that the results of this study have high validity by obtaining a result of $66.7 \%$, although the data used is very limited, only 9 months. Thus the ANN method is very effective in obtaining the results of this study.

\subsubsection{Conventional Banking CBGB 2}

Likewise, the results obtained from the N logarithm (5-1-1) in conventional banking BUKU 2, namely the value of the ROC (Receiver Operating Characteristics) curve of $95 \%$. This result strongly strengthens the findings of 
Fakhri \& Darmawan | Comparison of Islamic and Conventional Banking Financial Performance during the Covid-19 Period

financial performance factors in conventional banking. Figure 8 is described the result of the $N$ logarithm (6-1-1), namely the ROC (Receiver Operating Characteristics) curve.

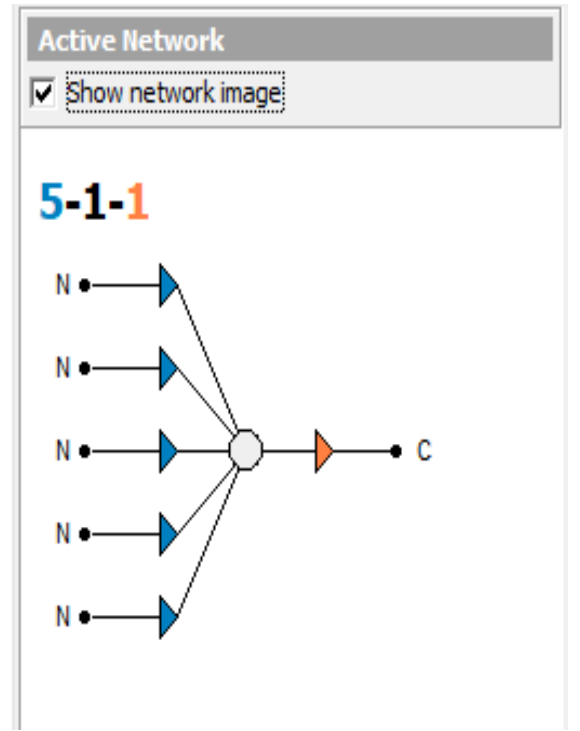

Figure 8. Logarithm of Conventional Banking CBGB 2

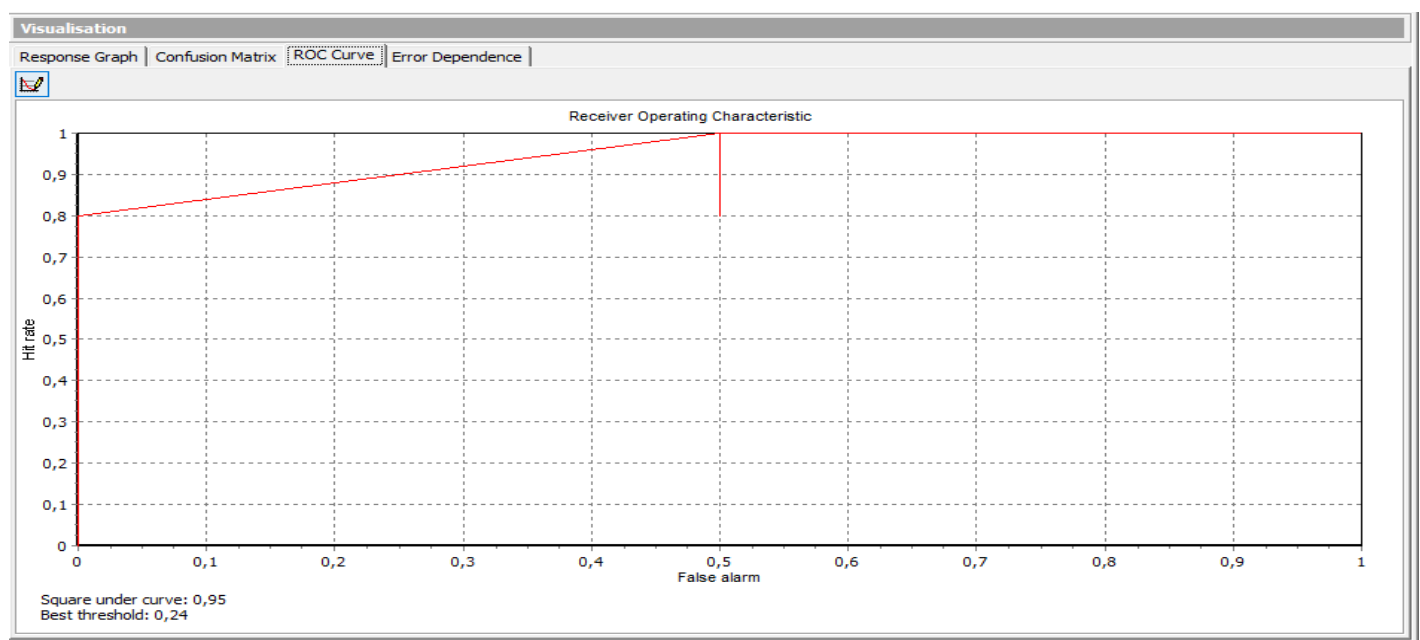

Figure 9. ROC Curve for Conventional Banking CBGB 2

The curve on Figure 9 shows a very significant result, even with limited data. The results of the ROC curve show that the ANN (Artificial Neural Network) Model is very good for use with limited data.

\subsection{Analysis}

This section discusses the comparison of factors affecting financial performance between Islamic banking CBGB 2 and conventional banking CBGB 2. Table 1 below explains the differences between the two. 
Fakhri \& Darmawan | Comparison of Islamic and Conventional Banking Financial Performance during the Covid-19 Period

Table 1. Comparison of the financial performance of Islamic Banking and Conventional CBGB 2.

\begin{tabular}{|c|c|c|}
\hline \multirow[b]{2}{*}{ Information } & \multicolumn{2}{|r|}{ Result } \\
\hline & Islamic & Conventional \\
\hline Logarithm & $5-1-1$ & $5-1-1$ \\
\hline CCR & $57.1 \%$ & $71.4 \%$ \\
\hline ROC Curve & $66.7 \%$ & $95 \%$ \\
\hline \multirow{4}{*}{$\begin{array}{l}\text { Financial Performance } \\
\text { Factors }\end{array}$} & 1. Funding to Deposit & 1. Operating Expenses to Operations \\
\hline & Ratio of $35.21 \%$ & Revenue of $72.87 \%$. \\
\hline & $\begin{array}{l}\text { 2. Net Operation Margin } \\
\text { of } 27.83 \%\end{array}$ & 2. Core Capital Ratio of $17.31 \%$ \\
\hline & $\begin{array}{l}\text { 3. Short Term Mismatch of } \\
26.92 \%\end{array}$ & 3. Liquid Asset Ratio of $5.35 \%$ \\
\hline
\end{tabular}

Table 1 shows that the modeling process using ANN is relatively the same. The Artificial Neural Network logarithm resulting from the CCR (Correct Classification Rate) is the same between Islamic banking and conventional CBGB 2 banking, although the values generated by the CCR (Correct Classification Rate) and the ROC (Receiver Operating Characteristics) curve are very different. Thus, this value can indicate the results obtained in the form of factors affecting financial performance between Islamic and conventional banks having the same validity. So, the results can be compared between Islamic and conventional banking.

The difference in factors that affect the performance of Islamic banking and conventional CBGB 2 is very significant due to the COVID-19 pandemic. This condition is a test for both Islamic and conventional banking in overcoming the company's financial crisis. The results of the above research prove that CBGB 2 Islamic banking is very vulnerable to external conditions. Meanwhile, Conventional Banking is still relatively safe with externals (COVID-19 pandemic).

The difference in financial performance between Islamic and conventional banking is in the first place, where Islamic banking has a significant influence on the FDR (Funding to Deposit Ratio) factor or liquidity factor of $35.21 \%$, when combined with the third order, namely Short Term Mismatch (STM) of $26.92 \%$, the liquidity factor has a very significant effect with a total of $62.13 \%$. Meanwhile, conventional banking has a very significant effect is the Profitability factor or Operating Expenses to Operations Revenue of $72.87 \%$. These results identify that Islamic banking is very difficult to pay off its debt and short-term obligations, due to Islamic banking prudence in channeling funds during the Covid-19 pandemic. Unlike Islamic banking, conventional banking has an effect on operational costs. The second and third ranks of conventional banking are the Capital Adequacy Ratio of $17.31 \%$ and the Liquid Asset Ratio of $5.35 \%$. This result affects capital adequacy and liquidity 
Fakhri \& Darmawan | Comparison of Islamic and Conventional Banking Financial Performance during the Covid-19 Period

insignificantly. Meanwhile, Islamic banking in the second place affects the Net Operation Margin (NOM) of $27.83 \%$. This result affects the factor of profitability or the ability of banks to earn profits.

The results above indicate that this study is in accordance with previous research, namely research by Fakhri et al. (2019), where Islamic banking is more vulnerable to the impact of the COVID-19 pandemic than conventional banking. The vulnerability of Islamic banking was evident at the time of the COVID-19 pandemic, where the pandemic affected very fundamental factors for Islamic banking, such as the liquidity factor which shows the ability of Islamic banking to meet short-term obligations, and profitability factors, such as the ability of Islamic banking to benefit. Whereas in conventional banking, the pandemic has a dominant influence on the Operating Expenses to Operations Revenue, which is the ability of conventional banks to manage company expenses and revenues. These obstacles can be overcome by making efficiency in company expenses.

\section{Conclusion and Recommendation}

\subsection{Conclusion}

The COVID-19 pandemic that has spread in Indonesia has affected economic growth. Likewise with banking which has greatly influenced the spread of COVID-19. In Islamic banking, it has a significant influence on the FDR (Funding to Deposit Ratio) factor or the liquidity factor of $35.21 \%$, when combined with the third order, namely Short Term Mismatch (STM) of 26.92\%. The liquidity factor has a very significant effect with a total of $62.13 \%$. Meanwhile, conventional banking which has a very significant influence is the Profitability factor or Operating Expenses on Operating Income of $72.87 \%$. These results identify that Islamic banking is very difficult to pay off its short-term debt and obligations, due to the prudence of Islamic banks in channeling funds during the Covid-19 pandemic. In contrast to Islamic banking, conventional banking affects operational costs. These obstacles can be overcome by making efficiency in company expenses. This result is strengthened by the similarity between the logarithms between conventional and Islamic banks, which is the result of the CCR (Correct Classification Rate) curve, so that it can be compared with one another.

From the results of this study, it is known that CBGB 2 Islamic banking is more vulnerable to external conditions, so it is hoped that Islamic banking can improve its financial liquidity as one of the financial performance factors that are affected by external conditions (COVID-19) so that in the future Islamic banking will more resistant to external conditions. Whereas in conventional

International Journal of Islamic Economics and Finance (IJIEF), 3(SI), 19-40 35 
Fakhri \& Darmawan | Comparison of Islamic and Conventional Banking Financial Performance during the Covid-19 Period

banking, the pandemic has a dominant influence on the Operating Expenses to Operations Revenue, which is the ability of conventional banks to manage company expenses and revenues. These obstacles can be overcome by making efficiency in company expenses.

\subsection{Recommendation}

Based on the results of the above research, Islamic banks need to make several improvements in order to be more resilient to external conditions, including strengthening liquidity management, carrying out efficiency and managing the quality of financing. Ismal (2010) in his research stated that the strategy of Islamic banking is to strengthen liquidity management by restructuring liquidity management in terms of both assets and liabilities. Restructuring in terms of assets is by channeling equity-based financing, intensively distributing funds in a syndicated manner, participating in funding companies that receive state development projects, strictly adjusting the funding and financing period. Meanwhile, in terms of liabilities, by innovating more varied fund collection products, collecting funds with a longer term, managing government funds / priority customers.

Islamic banks need to make efficiency by saving ineffective operational costs while improving the performance of financing distribution and placement of funds so as to increase operating income more optimally. Islamic banks are also required to absorb funds and channel financing optimally so that they can carry out the financial intermediation function more efficiently.

Apart from strengthening liquidity management and carrying out efficiency, Islamic banks also need to manage the quality of financing more optimally because the main source of income for Islamic banks comes from distribution of financing.

Several things that need to be done by Sharia Commercial Banks in channeling financing are paying attention to the principle of prudence in every channel of funds to customers, conducting proper financing analysis and mitigating risks on each fund channel, monitoring financing customers more closely to avoid side streaming of the use of funds starting from disbursement of financing, distribution of funds to relatively safe industrial sectors, distribution of financing using a Sharia Commercial Banks syndication scheme to companies that handle government infrastructure projects, distribution of financing to customers who have a good reputation.

In the current Covid-19 pandemic, conventional banks are still able to carry out the banking intermediary function by channeling them to industrial 
Fakhri \& Darmawan | Comparison of Islamic and Conventional Banking Financial Performance during the Covid-19 Period

sectors that are not or slightly affected by Covid19. Referring to the official report of the Central Statistics Agency for the second quarter of 2020, there are several business sectors that can still grow year on year (yoy) in the second quarter, namely the agricultural sector, information and communication, financial services, education, services, real estate, services, health and water supply. Meanwhile, the business sectors that can still grow quarterly or from quarter I to quarter II of 2020 are agriculture, information and communication as well as the provision of clean water. 
Fakhri \& Darmawan | Comparison of Islamic and Conventional Banking Financial Performance during the Covid-19 Period

\section{References}

Ali, A. M. (2020). The impact of economic blockade on the performance of Qatari Islamic and conventional banks: a period-and-group-wise comparison. ISRA International Journal of Islamic Finance, 12(3), 419441

Al-Osaimy, M.H, (1998), Neural network system for predicting islamic bank performance, JKAU: Econ. \& Adm., 11, 33-46.

Al-Shayea, Q. K., \& El-Refae, G. A. (2012). Evaluation of banks' insolvency using artificial neural networks. In Proceedings of the 11th WSEAS international conference on Artificial Intelligence, Knowledge Engineering and Data Bases (AIKED'12), Cambridge, United Kingdom (pp. 22-24).

Almilia, L. S., \& Kristijadi, K. (2003). Analisis rasio keuangan untuk memprediksi kondisi financial distress perusahaan manufaktur yang terdaftar di bursa efek jakarta. Jurnal Akuntansi dan Auditing Indonesia. Universitas Islam Indonesia, 7(2).

Anwar, S., \& Watanabe, K. (2011). Performance comparison of multiple linear regression and artificial neural networks in predicting depositor return of Islamic Bank. In 2010 International Conference on Ebusiness, Management and Economics (IPEDR), 3.

Bank Indonesia. (2020). Laporan Nusantara. Retrieved from https://www.bi.go.id/id/publikasi/laporan/Pages/Laporan-

Nusantara-Agustus-2020.aspx\#.

Boyacioglu, M. A., Kara, Y., \& Baykan, Ö. K. (2009). Predicting bank financial failures using neural networks, support vector machines, and multivariate statistical methods: A comparative analysis in the sample of savings deposit insurance fund (SDIF) transferred banks in Turkey. 36(2), 3355-3366.

Badan Pusat Statistik. (2020). Economic Growth of Indonesia. Retrieved from https://www.bps.go.id/website/materi_ind/materiBrsInd20200805114633.pdf.

Brédart, X. (2014). Bankruptcy prediction model using neural networks. Accounting and Finance Research, 3(2), 124-128.

Fakhri, U. N., Anwar, S., Ismal, R., \& Ascarya, A. (2019). Comparison and Predicting Financial Performance of Islamic and Conventional Banks in Indonesia to Achieve Growth Sustainability. al-Uqud: Journal of Islamic Economics, 3(2), 174-187.

Fakhri, U. N., Anwar, S., \& Ismal, R. (2020). Comparison of Islamic and Conventional Banking Bankruptcy Rates in Indonesia. Tazkia Islamic Finance and Business Review, 13(2).

Hamdi, M. (2012: 374-382), Prediction of financial distress for Tunisian firms: a comparative study between financial analysis and neuronal analysis. Business Intelligence Journal, 5(2). 
Fakhri \& Darmawan | Comparison of Islamic and Conventional Banking Financial Performance during the Covid-19 Period

Ika, S. R., \& Abdullah, N. (2011). A comparative study of financial performance of Islamic banks and conventional banks in Indonesia. International Journal of Business and Social Science, 2(15).

Ismal, R. (2010). Strengthening and improving the liquidity management in Islamic banking. Humanomics, 26(1), pp. 18-35.

Khrawish, H. A. (2011). Determinants of commercial banks performance: evidence from Jordan. International Research Journal of Finance and Economics, 81, 148-159.

Mawardi, W. (2005). Analisis faktor faktor yang mempengaruhi kinerja keuangan bank umum di Indonesia (studi kasus pada bank umum dengan total asset kurang dari 1 trilyun). Jurnal Bisnis Strategi, 14(1), 85.

Muljono, T. P. (1999). Aplikasi Akuntansi Manajemen Dalam Praktik Perbankan, Edisi 3, BPFE Yogyakarta.

Nugroho, L., Utami, W., \& Doktoralina, C. M. (2020). COVID-19 and the Potency of Disruption on the Islamic Banking Performance (Indonesia Cases). International Journal Economic And Business Applied, 1(1), 1125.

Odom, Marcus D., \& Sharda, R. (1990). A neural network model for bankruptcy prediction. Neural Networks, 1990, 1990 IJCNN International Joint Conference on. IEEE.

Peraturan Otoritas Jasa Keuangan. (2016). Transparansi dan Publikasi Laporan Bank. Retrieved from https://www.ojk.go.id/id/kanal/perbankan/regulasi/peraturanojk/Documents/Pages/POJK-tentang-Perubahan-RegulasiTransparansi-dan-Publikasi-Laporan-Bank/POJK-PublikasiTransparansi.pdf.

Setiawan, W. (2008). Prediksi harga saham menggunakan jaringan syaraf tiruan multilayer feedforward network dengan algoritma backpropagation. Konferensi Nasional Sistem dan Informatika 2008 (KNSdan108-020), 6.

Surat Edaran Otoritas Jasa Keuangan. (2019). Tingkat kesehatan perusahaan pembiayaan dan perusahaan pembiayaan syariah. Retrieved from https://ojk.go.id/id/regulasi/otoritas-jasa-keuangan/rancanganregulasi/Documents/RSEOJK\%20TKS\%20PP_Lampiran\%203.pdf.

Susanto, Y. K., dan Njit, T. F. (2012). Penentu kesehatan perbankan. Jurnal Bisnis dan Akuntansi, 14(2), 105-116.

Otoritas Jasa Keuangan. (2020). Statistik Perbankan Indonesia. Retrieved from https://www.ojk.go.id/id/kanal/perbankan/data-danstatistik/statistik-perbankan-indonesia/Pages/Statistik-PerbankanIndonesia---Desember-2020.aspx.

Tam, K .Y, (1991), Neural network models and the prediction of bank bankruptcy, Science Direct Journal, Volume 19, Issue 5, Pages 429-445 
Fakhri \& Darmawan | Comparison of Islamic and Conventional Banking Financial Performance during the Covid-19 Period

Tam, K. Y. dan Kiang, M.Y, (1992), Managerial applications of neural networks: The case of bank failure predictions, Management Science in inform publication, 38, 926-947.

Tho'in, M., (2019). The comparison of Islamic banking financial performance in Indonesia. International Journal of Scientific Research and Education, 7(5). 